\title{
Look Closer
}





\section{Look Closer}

\section{Suburban Narratives and American Values in Film and Television}

DAVID R. COON

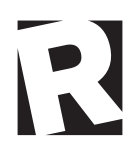

RUTGERS UNIVERSITY PRESS

NEW BRUNSWICK, NEW JERSEY, AND LONDON 
Coon, David R., I974-

Look closer : suburban narratives and American values in film and television / David R. Coon.

p. cm.

Includes bibliographical references and index.

ISBN 978-O-8I35-6208-7 (hardcover : alk. paper) - ISBN 978-O-8I35-6207-O (pbk. : alk. paper) - ISBN 978-0-8I35-6209-4 (e-book)

I. Suburban life in motion pictures. 2. United States-In motion pictures.

3. Suburban life on television. 4. United States-On television. I. Title. PNi995.9.S74C66 2013 79I.43'62-dc23 201300597I

A British Cataloging-in-Publication record for this book is available from the British Library.

Copyright (C) 2014 by David R. Coon

All rights reserved

No part of this book may be reproduced or utilized in any form or by any means, electronic or mechanical, or by any information storage and retrieval system, without written permission from the publisher. Please contact Rutgers University Press, I06 Somerset Street, New Brunswick, NJ 089oI. The only exception to this prohibition is "fair use" as defined by U.S. copyright law.

Visit our Web site: http://rutgerspress.rutgers.edu

Manufactured in the United States of America 